\title{
Developing Innovative Practices Through Third-Space Partnerships: Reflections on Project DARE (Dementia Knowledge, Art, Research and Education)
}

Corinne A. Green, BEd

University of Wollongong, Wollongong, New South Wales, Australia

iD https://orcid.org/0000-0001-9274-8275

Michelle J. Eady, PhD

University of Wollongong, Wollongong, New South Wales, Australia

(iD https://orcid.org/0000-0001-5624-0407

Pippa Burns, PhD

University of Wollongong, Wollongong, New South Wales, Australia iD https://orcid.org/o0oo-0001-7446-8691

Jessica Baker, $\mathrm{PhD}$

University of New South Wales, Sydney, New South Wales, Australia

(iD) https://orcid.org/o0oo-0002-5578-1727

Jennine Primmer, MA

Wollongong City Council, Wollongong, New South Wales, Australia

Penelope Harris, DCA

University of Wollongong, Wollongong, New South Wales, Australia

iD https://orcid.org/0000-0001-8645-6671

Carinya Barkley, BSc, GDipEd

Coledale Public School, Coledale, New South Wales, Australia

Victoria Traynor, $\mathrm{PhD}$

University of Wollongong, Wollongong, New South Wales, Australia

iD https://orcid.org/oooo-0003-4515-7602

Contact: corinneg@uow.edu.au

\section{Abstract}

Partnerships between schools, universities, and community organizations have mutual benefits for all involved. These partnerships value the contributions of all participants and capitalize on the expertise and knowledge that each brings. This reflective paper details a collaborative third-space partnership between a

Note: The authors would like to thank the staff at Thirroul Public School, in particular the Stage 2 teachers-Lesley Bennet, Carlie Brunton, Rhonda Gilogley, Ben Kirk, and Cameron Skinner-and the acting principal, Raquelle Hallam. We would also like to extend our thanks and acknowledge the time and input of the artists involved in the project: Nina Young, Laura Stekovic, and Angela Forrest. We couldn’t have done this without you.

Funding details: This project was supported by the University of Wollongong Global Challenges Program (internal grant).

Disclosure statement: The authors declare no conflict of interest. 
university, a primary school, and a community organization. The partnership facilitated the design, development, and implementation of a unique program called Project DARE (Dementia knowledge, Art, Research, and Education). A research-based evaluation of the Project DARE feasibility study can be found elsewhere (Burns et al., 2020). The aim of this paper is to reflect upon the formation of the partnership and the roles that each party played. It also discusses implications for the future development of third-space partnerships.

Keywords: third-space partnership; industry-university collaboration; dementia; art; health

Date Submitted: February 27, 2020 | Date Published: March 26, 2021

\section{Recommended Citation}

Green, C. A., Eady, M. J., Burns, P., Baker, J., Primmer, J., Harris, P., Barkley, C., \& Traynor, V. (2021). Developing innovative practices through third-space partnerships: Reflections on Project DARE (Dementia knowledge, Art, Research, and Education). Journal of Educational Research and Practice, 11, 34-45. https://doi.org/10.5590/JERAP.2021.11.1.03

\section{Teaching Content in a Primary School Classroom}

In Australia, primary school teachers are generalists responsible for addressing all six Key Learning Areas (KLAs)-English, Mathematics, Science \& Technology, Health \& Physical Education, Creative Arts, and History \& Geography. The primacy of literacy and numeracy teaching is clear within policy guidelines, high stakes testing, and from teachers' own experiences (Chapman, 2015; Polesel et al., 2014). As a result, less attention is often given to the remaining subjects (Polesel et al., 2014; Thompson \& Harbaugh, 2013). This issue is pervasive in schools across Australia and around the world (Hui et al., 2015; Polesel et al., 2014).

Teachers have expressed discomfort in teaching creative arts, health and physical education, science, and history, and geography (Freak \& Miller, 2017; Hamilton, 2013; Hast, 2017; Rollison et al., 2012). As a result, primary school teachers are often more comfortable leaving the responsibility of teaching these subjects to specialist teachers or external providers (Chapman, 2015; Lemon \& Garvis, 2013). This segregated approach means that each subject is taught separately from the others (Chapman, 2015; Ewing et al., 2011). This limits opportunities for cross-curricular learning where a lesson or unit incorporates more than one subject, demonstrating connectedness between subjects and making clear to students the relevance of their learning (Chapman, 2015; Lemon \& Garvis, 2013). It also leads to the sense of an overcrowded curriculum where teachers feel that there is not enough time to engage students deeply with content from all KLAs, and instead treat these so-called "fringe subjects" either superficially or not at all (Ewing et al., 2011; Lemon \& Garvis, 2013).

Integrating subject content across KLAs combats this overcrowding by "creating rich tasks that draw on a range of deeper learning experiences" (Chapman, 2015, p. 87). As well as being a valuable subject area in its own right, the Creative Arts KLA complements inquiry in other subjects as it "encourages creativity, the ability to foresee needs and problems, and respond imaginatively, innovatively and flexibly" (Hamilton, 2013, p. 195). The Creative Arts KLA provides opportunities for students to express themselves in sophisticated ways that are not limited by their literacy levels or vocabulary (Lemon \& Garvis, 2013; Shaban \& Al-Awidi, 2013). However, it is worth noting that content integration across multiple subjects is not a simple task (Stefanski et al., 2019).

\section{Put Under Pressure}

\section{Teachers}

Whether teachers take a separated or an integrated approach to teaching KLA content, they are under significant pressure from multiple directions (Kronborg \& Plunkett, 2012; Naghieh et al., 2015). Their work 
requires them to negotiate a range of demands from accrediting bodies, their school communities, and society at large (Lemon \& Garvis, 2013). Innovation is expected of teachers with regards to lesson activities, teaching and learning approaches, inclusivity, and digital technology use (Lemon \& Garvis, 2013; Naghieh et al., 2015).

\section{University academics}

Like teachers, university academics are under pressure to connect with and give back to their local community (Nelson \& Dodd, 2017). In Australia, it is imperative for universities to demonstrate their impact and engagement, with the allocation of federal research funding being determined by these factors (Australian Research Council, 2016). Universities demonstrate their commitment to their regional and global community by assessing end-user impact and through responsible research and quality teaching programs. However, enduser collaboration has previously been a point of under-performance within Australian research (Australian Research Council, 2016).

At the University of Wollongong, the Global Challenges program has been established to encourage this kind of community-engaged and impactful research (University of Wollongong, 2020). It aims to support collaborative teams with members from university, community groups, industry, and government to address global issues (such as dementia, cultural revitalization, ecological sustainability, disability inclusion, food security, and others) through localized responses that have the potential to be scaled up. In this way, the program promotes and supports academics to engage with local communities as they conduct "creative and community-engaged research that will help drive social, economic, and cultural change in our region, with the potential to be translatable across the globe" (University of Wollongong, 2020, n.p.).

\section{Working in the Third Space}

Innovative practices and approaches can be implemented through the establishment of sustainable partnerships between, for example, schools and universities (Green et al., 2020, Gross et al., 2015; Zeichner, 2010). These collaborative and non-hierarchical partnerships are concerned with the "third space" between the university and the school or community (Zeichner, 2010) (see Figure 1).

Figure 1: Visual Representation of Third Space

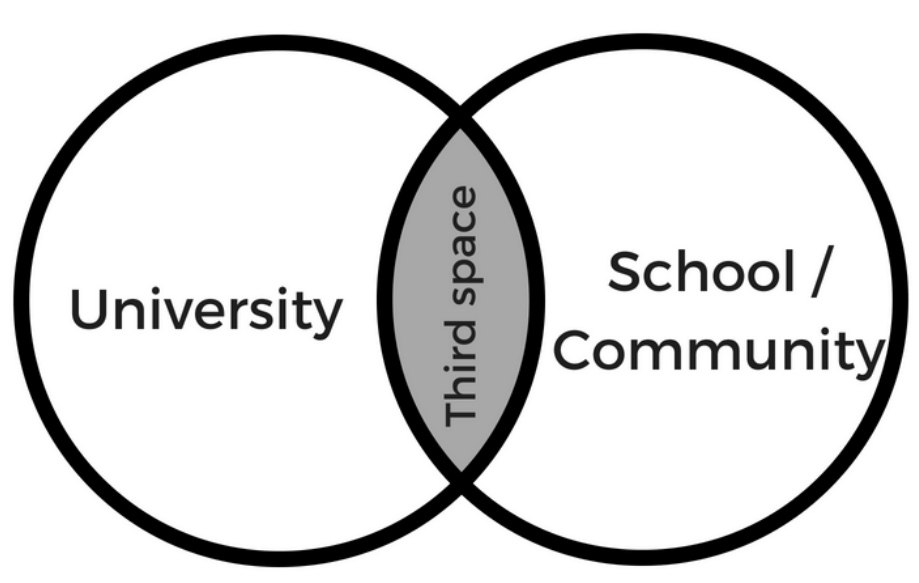

Within teacher education, school-university partnerships are increasingly used to provide authentic experiences for university students, professional learning for teachers, and research opportunities for academics and to enable collaborative curriculum development for school and university settings (Broadley et al., 2013; Jones et al., 2016; Lynch, 2013; Miller et al., 2015). Partnerships between universities and communities are similarly employed within other fields of higher education, including vocational courses such as medicine, nursing, and social work (Lewis et al., 2016; Mersky et al., 2017).

The ways that these partnerships are enacted vary widely based on the purpose and aims of the partnerships. For example, in many cases, professional learning courses are developed based on the needs of the school and the networks and expertise of the academics involved (Clary et al., 2015; Davis \& Watson, 2017; Kronborg \& Plunkett, 2012). Innovative school programs 
may be established, capitalizing on the knowledge and expertise of schoolteachers and university academics (Forgasz, 2016; Miller et al., 2015). In these instances, university academics provide content knowledge and evaluation expertise to assess the impact of the program (Lynch, 2013; Miller et al., 2015). Other partnerships may incorporate outreach programs that create pathways for school students to pursue higher education (Davis \& Watson, 2017).

Third-space partnerships between universities and community organizations are being employed in areas such as community development, food security, child welfare, health professional education, and teacher education (Green et al., 2020; Mersky et al., 2017; Nelson \& Dodd, 2017). Such connections enable the development and evaluation of evidence-based programs suited to the needs of the involved parties.

Regardless of the specific activities engaged in, there are demonstrable benefits for all those involved in thirdspace partnerships, including community development, improved school and university programs, and professional learning opportunities (Green et al., 2020; Nelson \& Dodd, 2017). While challenges exist within these partnerships, including the logistics of their operation and the role of key personnel, they frequently generate new opportunities that were not previously possible or feasible (Forgasz, 2016; Green et al., 2020).

\section{Method/Process}

Project DARE was developed within a third-space partnership between university (researchers at the University of Wollongong and the University of New South Wales), school (teachers at Thirroul Public School), and a community organization (artists from ArtSpace at Big Fat Smile) (see Figure 2). The purpose of this partnership was to create an innovative, evidence-based school program in which visual art was used to develop students' knowledge and understanding of dementia.

Figure 2: Third-Space Relationship Between the University, School, and Community Group

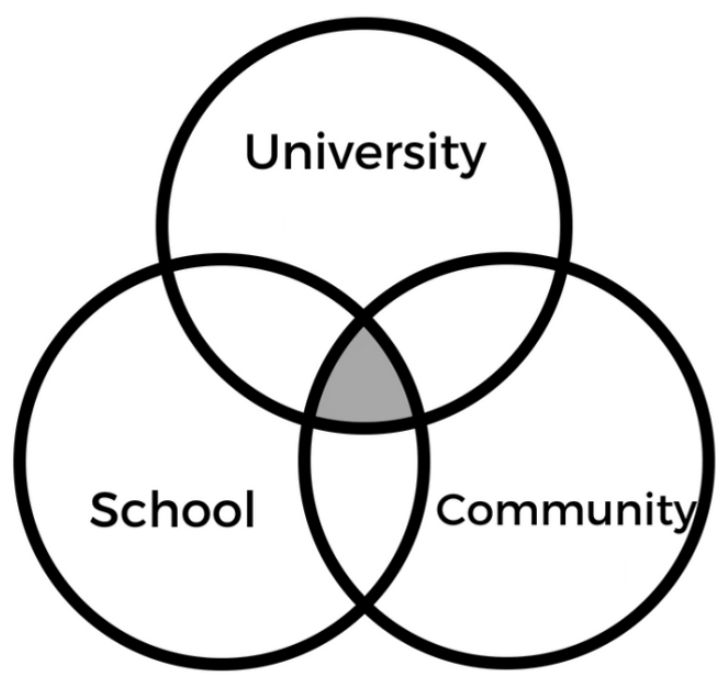

In the Project DARE feasibility study, Stage 2 students (Years 3 and 4, ages 8-10 years) from Thirroul Public School were involved in three lessons delivered once a week over three consecutive weeks. In these lessons, artists from ArtSpace at Big Fat Smile and teachers from Thirroul Public School facilitated students to create artworks representing how dementia might affect an individual. Further details of the feasibility study and its evaluation are reported in Burns et al. (2020). The remainder of this paper focuses on our reflections as the members of this third-space partnership and provides guidance for others seeking to establish similar partnerships. 


\section{Context of Each Group}

A new interdisciplinary team was formed for this project and successfully obtained seed funding from the Global Challenges program at the University of Wollongong. The Project DARE team consisted of:

- $\quad$ Pippa Burns (University of Wollongong, Faculty of Science, Medicine and Health, School of Medicine)

- Corinne Green (University of Wollongong, Faculty of Social Sciences, School of Education)

- Michelle Eady (University of Wollongong, Faculty of Social Sciences, School of Education)

- Jess Baker (University of New South Wales, Faculty of Medicine, School of Psychiatry)

- Jennine Primmer (Big Fat Smile, professional artist)

- Penny Harris (University of Wollongong, Faculty of Law, Humanities and the Arts, School of the Arts, English and Media)

- Carinya Barkley (Thirroul Public School, classroom teacher)

- Victoria Traynor (University of Wollongong, Faculty of Science, Medicine and Health, School of Nursing)

The project name, Project DARE, was chosen to reflect this broad range of expertise.

\section{Universities: University of Wollongong and University of New South Wales}

The diverse backgrounds of the university-based researchers (including education, nursing, medicine, art, and psychiatry) created a dynamic group with varied expertise. Pippa Burns and Victoria Traynor are experts in public health and dementia. Jess Baker has previous research experience teaching upper-primary school students (years 5 and 6) about dementia (Baker et al., 2017). This knowledge provided a valuable foundation for the project. As education experts, Michelle Eady and Corinne Green were able to ensure that the program was feasible within a school environment and that quality teaching elements and appropriate syllabus outcomes were integrated into the program. Penny Harris brought a wealth of understanding concerning the arts from an academic perspective, ensuring that the program incorporated authentic art-making techniques appropriate for the setting. Each of these areas of expertise was drawn upon in the development and evaluation of Project DARE (Burns et al., 2020).

\section{School: Thirroul Public School}

Thirroul Public School is located in a metropolitan area and is local to the university. It is in an area of relative socio-economic advantage (Australian Bureau of Statistics, 2016), comprised primarily of families. At the time of the study, there were 472 students enrolled from K-6 and 25 staff members (Australian Curriculum Assessment and Reporting Authority, 2020).

The project involved all four Stage 2 classes and teachers at the school. These teachers assisted the research and community team members in implementing the program. In addition, one of the teachers (Carinya Barkley) came forward during the early stages of the project with an interest in being intrinsically involved in the project team. Her nine years of experience as a primary school teacher and knowledge of the school environment brought additional expertise to the research team.

\section{Community group: ArtSpace at Big Fat Smile}

The artists involved in this feasibility project were from a local arts studio called ArtSpace-part of the not-forprofit organization, Big Fat Smile. The studio was a purpose-built visual arts studio for children aged 3-18. The degree-qualified professional artists ran term-based and holiday programs as well as an outreach 
program to preschool and primary schools. This provided them with extensive experience in teaching art to school-aged children. The artists involved in this project had diverse backgrounds, having previously worked in the areas of interior design, textiles design, photography, and production. Jennine Primmer from ArtSpace at Big Fat Smile was involved in the project from the early stages.

\section{Third-Space Interactions}

Throughout the program's development and implementation, a variety of third-space interactions existed between and among the university, school, and community partners.

\section{School and university}

Two members of the university research team had an existing relationship with the school-one as a parent and the other both as a parent and in a professional capacity. These relationships sparked initial discussions around the school being involved in the development and implementation of Project DARE. Future iterations of Project DARE are planned for other school settings, without these pre-existing relationships, to ensure the transferability of the research findings.

Strong links were formed between personnel from the school and the university in the development of the program, particularly as the education lesson was prepared. Michelle Eady and Carinya Barkley worked closely to plan engaging teaching and learning activities that were connected to syllabus content from the KLAs of Health and Physical Education, English, and Science. Pippa Burns, Victoria Traynor, and Jess Baker also contributed to this process in the form of identifying appropriate dementia information and resources. The whole team experienced the lesson in full and provided feedback before it was finalized and taught to the school students.

\section{Community and university}

The purposeful art-based lessons provided similar opportunities for collaboration between the community artists and university team members. The broad idea for the art lessons-a progressive artwork that students worked on-was discussed by Jennine Primmer (Big Fat Smile) and Penny Harris and Pippa Burns

(University of Wollongong), as well as the broader research team, to ensure it was aligned with the aims of the project. Jennine Primmer worked with both her team of artists and Penny Harris to flesh out the details of the lessons and then shared these with the research team. This iterative process resulted in authentic art-making activities that connected the Creative Arts, Health and Physical Education, and English KLAs, and was appropriate for the project.

\section{School and community and university}

All three groups were intricately involved in the implementation of the program, which took place onsite at Thirroul Public School. Carinya Barkley's teaching position at the school facilitated the logistics involved, including welcoming the university researchers and community artists to the school environment. It was decided by the school that Carinya Barkley's classroom would be used as the location for the program, with the Year 3 and 4 classes rotating through this room across each day of implementation (one day per week for three consecutive weeks). Class teachers remained with their classes through this rotation, supervising and assisting where needed across each lesson. The dementia education lesson in Week 2 of the program was taught by Carinya Barkley to each of the four classes of children across the day (see Figure 3). 


\section{Figure 3: Carinya Barkley Teaching Stage 2 Students About Dementia}

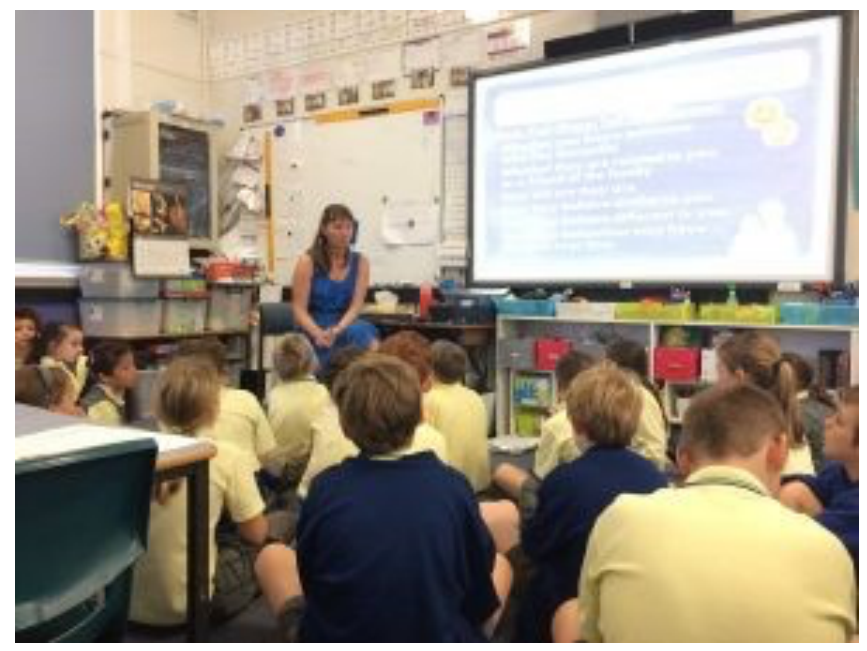

Jennine Primmer worked closely with personnel from the school and university throughout the development of the arts-based lessons and their implementation. This enabled a professional, practicing artist to collaborate with an art academic (Penny Harris) as well as educators with no formal arts training (Carinya Barkley and Michelle Eady). In Week 1 and Week 3 of the program, the qualified community artists were onsite to deliver the artsbased lessons. They were responsible for leading each class in the learning activities throughout the day and providing art materials.

While all participants in the third-space partnership were equally valued, the university researchers had responsibility to drive the project from formation to conclusion. Several of the university researchers were onsite to assist with the program implementation each week. The researchers were also responsible for the evaluation of the program (Burns et al., 2020). This included facilitating the collection of pre- and post-surveys with each class and undertaking interviews with students about their artworks. They also ensured that protocols outlined in the ethics approval (e.g., the codification of artworks) were followed appropriately.

Working together at the school, with university academics contributing alongside the schoolteachers and artists from the community, created a rewarding team camaraderie that was maintained from the beginning to end of the project. We believe that the third-space partnership we developed, with relationships, teamwork, and collegiality at its core, was paramount to the success of this project.

\section{Figure 4: Photos Taken at the Big Fat Smile Exhibition Launch}

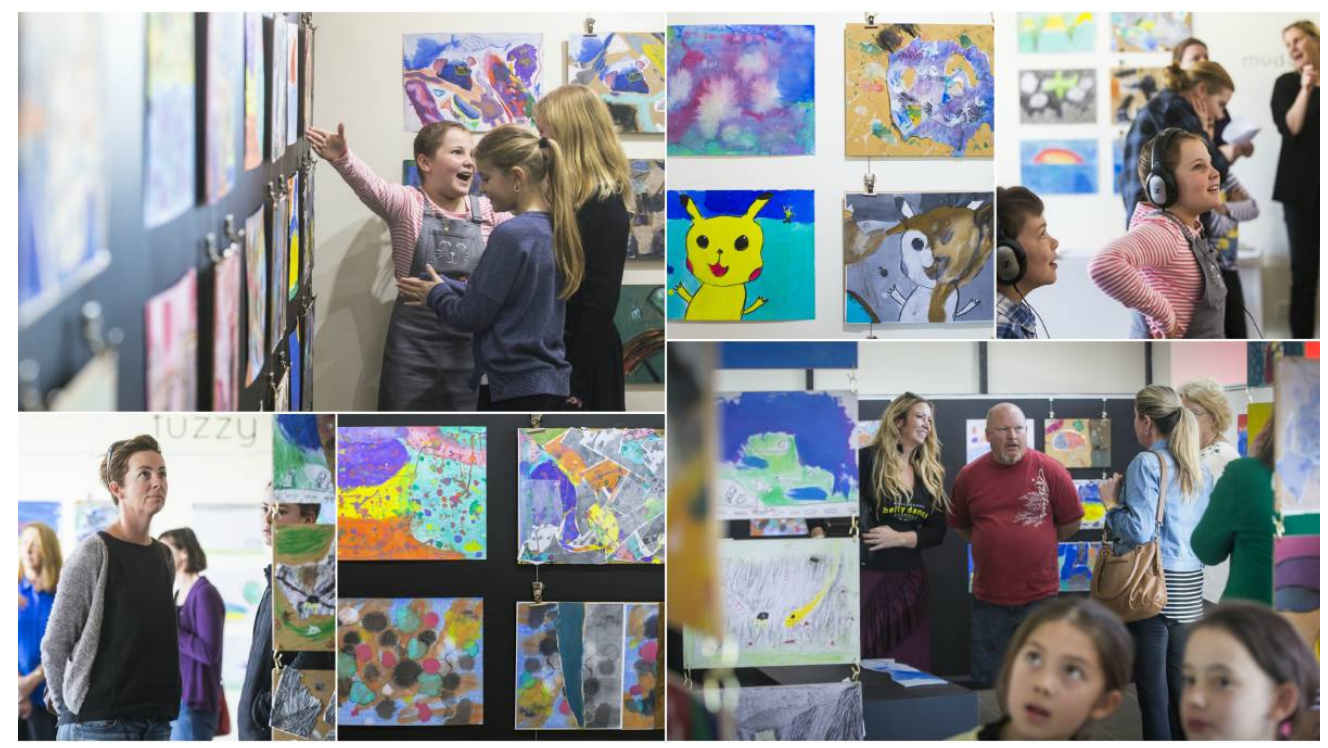

In addition to being involved in the delivery of the program at the school, all three groups collaborated to hold two exhibitions of student artworks. The first of these took place at Big Fat Smile's gallery space and was curated by Jennine Primmer. The participating students and their families and Project DARE team members, along with members of the public and local media, attended the exhibition launch (see Figure 4). A second exhibition of artworks, curated by Penny Harris, took place at University of Wollongong. This exhibition was open to the public and also visited by attendees of the Global Challenges annual conference. 
Green et al., 2021

\section{Reflections and Discussion}

In this section, we aim to make explicit our reflections regarding our partnerships and how they provided a firm and collaborative foundation for developing and implementing the Project DARE feasibility study. The results and implications of Project DARE itself are reported elsewhere (Burns et al., 2020).

The interdisciplinary research team provided opportunities for the researchers involved to utilize their areas of expertise, foster learning from diverse fields of work, and share knowledge and experience with colleagues from other faculties (Townsend et al., 2015). These interdisciplinary ways of working also enabled each member to contribute their strengths to the project and granted them the opportunity to learn from other team members. As identified by Townsend et al. (2015), an interdisciplinary team involves collaboration, evolving in joint work and resulting in an enhanced research performance. Each team member provided not only expertise but also support and collegiality in aiding the rest of the team to understand the importance of the project and the steps taken to create the learning experience from their perspective. This was also seen in the work of Solis (2017) and Jin et al. (2017), where interdisciplinary teams were formed to explore complex and multidisciplinary problems.

We encountered challenges throughout the development and implementation of Project DARE, including the time and energy required of all team members to work collaboratively over an extended period. The partnership also presented risks, with potential damage to the team members' and organizations' reputations if the project were to be stalled or disbanded entirely. Additionally, three team members (Carinya Barkley, Jennine Primmer, and Pippa Burns) have changed professional roles since the commencement of the partnership, and Big Fat Smile's ArtSpace art studio no longer operates. However, in our experience, these challenges did not inhibit our collaborative efforts. All parties have demonstrated ongoing interest in Project DARE and are keen to maintain an active partnership and find other ways of working together.

The artists were enthusiastic about the opportunity this project presented to build relationships with the school and the university and provide authentic and purposeful art lessons catered to all students involved (Chapman, 2015; Hamilton, 2013). They were proud to showcase the quality of the students' artworks through the art exhibition at Big Fat Smile's gallery space, with the students and their families invited to the public exhibition launch (see Figure 4). A valuable outcome of this project was that the art exhibitions attracted community members to a place where many had not previously visited. Thus the project contributed to building the community as a whole and initiating conversations about dementia at a community level (Nelson \& Dodd, 2017).

A common thread running through all of the third-space interactions in this project was respectful relationships. All participants in third-space partnerships, such as those described in this paper, need an open mind and a willingness to collaborate (Gross et al., 2015). It was crucial with this project, and those described elsewhere in the research literature (Broadley et al., 2013; Jones et al., 2016), that time was taken to build relationships that valued all participants equally, whether they were connected to the school, university, or community. All parties involved in the project were treated as peers and colleagues throughout the process, and their unique areas of expertise were valued consistently. Building relationships across partnerships provides ongoing collegiality and long-term opportunities (Jones et al., 2016; Lynch, 2013).

The diverse expertise inherent in this partnership was also a factor in the project's success. Being able to draw upon the knowledge, skills, and understanding of a range of academics (Pippa Burns, Corinne Green, Michelle Eady, Jess Baker, Penny Harris, and Victoria Traynor), a professional artist (Jennine Primmer), and a practicing teacher (Carinya Barkley) from the outset of this project ensured that we were able to utilize best practice in all aspects of developing and implementing Project DARE. The iterative process followed throughout the project facilitated multiple points of feedback from all parties. It also ensured an inclusive approach, with Jennine Primmer and Carinya Barkley present at the university-based meetings regarding 
grant applications and ethics submissions and providing input into the dissemination of findings. This valuing and enhancing of each member's expertise was a common feature within the literature on third-space partnerships (Clary et al., 2015; Kronborg \& Plunkett, 2012; Miller et al., 2015).

As recognized in previous work, the availability of resources within Project DARE (from multiple sources) aided its success (Lynch, 2013; Miller et al., 2015). Funding was accessed through the university via the Global Challenges program, which paid for a research assistant and incidental costs associated with the project. Big Fat Smile contributed some of the art materials required for each of the art lessons and provided gallery space, curatorial hours, and advertising for the first of the art exhibitions. Thirroul Public School provided in-kind contributions related to the implementation of Project DARE within their school. In this way, each party demonstrated their commitment to the partnership through their investment of time, money, and resources (Broadley et al., 2013; Jones et al., 2016; Miller et al., 2015).

\section{Conclusion}

Project DARE is an example of what can be achieved when a university, school, and community come together, in a way in which everyone's expertise is valued, to address complex problems. In sharing our reflections regarding the partnership that made Project DARE possible, we hope we provide guidance to others seeking to establish a third-space partnership. In our case, it provided a unique, fresh, and meaningful approach to educating children about a topic that is important in our society. 


\section{References}

Australian Bureau of Statistics. (2016). Census of population and housing: Socio-economic indexes for areas (SEIFA) 2016. Australian Bureau of Statistics. https://www.abs.gov.au

Australian Curriculum Assessment and Reporting Authority. (2020). Thirroul Public School. https://myschool.edu.au/school/42821

Australian Research Council. (2016). National Innovation and Science Agenda: Engagement and impact assessment consultation paper. Commonwealth of Australia.

Baker, J. R., Low, L.-F., Goodenough, B., Jeon, Y.-H., Tsang, R. S. M., Bryden, C., \& Hutchinson, K. (2017). The Kids Insight into Dementia Survey (KIDS): development and preliminary psychometric properties. Aging \& Mental Health, 1-7. https://doi.org/10.1080/13607863.2017.1320703

Broadley, T., Sharplin, E., \& Ledger, S. (2013). New frontiers or old certainties: The pre-service teacher partnership. In D. E. Lynch \& T. Yeigh (Eds.), Teacher education in Australia: Investigations into programming, practicum and partnership (pp. 94-108). Oxford Global Press.

Burns, P., Green, C. A., Eady, M. J., Baker, J. R., Harris, P., Primmer, J., Barkley, C., \& Traynor, V. (2020). Dementia knowledge, Art, Research, and Education: Teaching primary school children about dementia. Health Promotion Journal of Australia. https://doi.org/10.1002/hpja.424

Chapman, S. N. (2015). Arts immersion: Using the arts as a language across the primary school curriculum. Australian Journal of Teacher Education, 4O(9), 86-101. https://doi.org/10.14221/ajte.2015v40n9.5

Clary, D., Feez, S., Garvey, A., \& Partridge, R. (2015). From little things big things grow: Enhancing literacy learning for secondary students in rural and regional Australia. Australian \& International Journal of Rural Education, 25(1), 24-36.

Davis, G. M., \& Watson, E. (2017). Creating an online information literacy course for concurrent enrollment students: A collaboration with a state-sponsored online school. College and Undergraduate Libraries, 24(1), 29-50. https://doi.org/10.1080/10691316.2016.1190676

Ewing, R., Hristofski, H., Gibson, R., Campbell, V., \& Robertson, A. (2011). Using drama to enhance literacy: The "school drama" initiative. Literacy Learning: The Middle Years, 19(3), 33-39.

Forgasz, R. (2016). Rethinking the observation placement: A community/cohort approach to early professional experiences. In R. Bradenburg, S. McDonough, J. Burke, \& S. White (Eds.), Teacher education: Innovation, intervention and impact (pp. 99-116). Springer. https://doi.org/10.1007/978-981-10-0785-9

Freak, A., \& Miller, J. (2017). Magnifying pre-service generalist teachers' perceptions of preparedness to teach primary school physical education. Physical Education \& Sport Pedagogy, 22(1), 51-70. https://doi.org/10.1080/17408989.2015.1112775

Green, C. A., Tindall-Ford, S. K., \& Eady, M. J. (2020). School-university partnerships in Australia: A systematic literature review. Asia-Pacific Journal of Teacher Education, 48(4), 403-435. https://doi.org/10.1080/1359866X.2019.1651822

Gross, J. M. S., Haines, S. J., Hill, C., Francis, G. L., Blue-Banning, M., \& Turnbull, A. P. (2015). Strong school-community partnerships in inclusive schools are "part of the fabric of the school.... We count on them." School Community Journal, 25(2), 9-34.

Hamilton, A. (2013). Preparing to teach the arts in primary school. In P. Hudson (Ed.), Learning to teach in the primary school (pp. 188-207). Cambridge University Press. 
Hast, M. (2017). Technology and early science education: Examining generalist primary school teachers' views on tacit knowledge assessment tools. International Education Studies, 1O(11), 135-147. https://doi.org/10.5539/ies.v10n11p135

Hui, A. N. N., He, M. W. J., \& Ye, S. S. (2015). Arts education and creativity enhancement in young children in Hong Kong. Educational Psychology, 35(3), 315-327. https://doi.org/10.1080/01443410.2013.875518

Jin, Z., Zhong, B., Wang, X., \& Jiang, H. (2017). The mechanism of knowledge associated integration of interdisciplinary research team based on absorption ability. MATEC Web of Conferences, 100, 50385045. https://doi.org/10.1051/matecconf/201710005038

Jones, M., Hobbs, L., Kenny, J., Campbell, C., Chittleborough, G., Gilbert, A., Herbert, S., \& Redman, C. (2016). Successful university-school partnerships: An interpretive framework to inform partnership practice. Teaching and Teacher Education, 6o, 108-120. https://doi.org/10.1016/j.tate.2016.08.006

Kronborg, L., \& Plunkett, M. (2012). Examining teacher attitudes and perceptions of teacher competencies required in a new selective high school. Australasian Journal of Gifted Education, 21(2), 33-46.

Lemon, N., \& Garvis, S. (2013). What is the role of the arts in a primary school? An investigation of perceptions of pre-service teachers in Australia. Australian Journal of Teacher Education, 38(9). https://doi.org/10.14221/ajte.2013v38n9.7

Lewis, L. A., Kusmaul, N., Elze, D., \& Butler, L. (2016). The role of field education in a university-community partnership aimed at curriculum transformation. Journal of Social Work Education, 52(2), 186-197. https://doi.org/10.1080/10437797.2016.1151274

Lynch, T. (2013). School Centres for Teaching Excellence (SCTE): Understanding new directions for schools and universities in Health and Physical Education. Asia-Pacific Journal of Health, Sport and Physical Education, 4(3), 249-266. https://doi.org/10.1080/18377122.2013.836770

Mersky, J. P., Topitzes, J., \& Blair, K. (2017). Translating evidence-based treatments into child welfare services through community-university partnerships: A case example of parent-child interaction therapy. Children and Youth Services Review, 82, 427-433. https://doi.org/10.1016/j.childyouth.2017.10.002

Miller, J., Haynes, J. E., \& Pennington, J. (2015). A partnership aimed at improving health and physical education at a rural school: Impacts on pupils, university students, teachers and academics. Australian \& International Journal of Rural Education, 25(2), 56-72.

Naghieh, A., Montgomery, P., Bonell, C. P., Thompson, M., \& Aber, J. L. (2015). Organisational interventions for improving wellbeing and reducing work-related stress in teachers. Cochrane Database of Systematic Reviews, 4, 1-72. https://doi.org/10.1002/14651858.CD010306.pub2

Nelson, E., \& Dodd, W. (2017). Collaborating for community food security: Emerging scholar participation in a community-university partnership. Action Research, 15(4), 402-423. https://doi.org/10.1177/1476750316656041

Polesel, J., Rice, S., \& Dulfer, N. (2014). The impact of high-stakes testing on curriculum and pedagogy: A teacher perspective from Australia. Journal of Education Policy, 29(5), 640-657. https://doi.org/10.1080/02680939.2013.865082

Rollison, J. M., Ludlow, L. H., \& Wallingford, T. (2012). Assessment content knowledge and changes in confidence and anxiety related to economic literacy in a professional development program for history teachers. Journal of Educational Research and Practice, 2(1), 15-30. https://doi.org/10.5590/JERAP.2012.02.1.02 
Shaban, M. S., \& Al-Awidi, H. M. (2013). Understanding Emirati children's drawing in relation to self and identity through the interaction of social context. Journal of Research in Childhood Education, 27(3), 330-350. https://doi.org/10.1080/02568543.2013.795508

Solis, G. R. (2017). To give and to get: How nurse faculty scholars contribute and benefit from participating in interdisciplinary research teams. Nursing Forum, 52(2), 133-137. https://doi.org/10.1111/nuf.12188

Stefanski, A. J., Martin, N. M., \& Zurcher, M. A. (2019). Science-literacy integration: Equity and learning in first-grade, urban instructional contexts. Journal of Educational Research and Practice, 9(1), 104123. https://doi.org/10.5590/JERAP.2019.09.1.08

Thompson, G., \& Harbaugh, A. G. (2013). A preliminary analysis of teacher perceptions of the effects of NAPLAN on pedagogy and curriculum. Australian Educational Researcher, 4O(3), 299-314. https://doi.org/10.1007/s13384-013-0093-0

Townsend, T., Pisapia, J., \& Razzaq, J. (2015). Fostering interdisciplinary research in universities: A case study of leadership, alignment and support. Studies in Higher Education, 4O(4), 658-675. https://doi.org/10.1080/03075079.2013.842218

University of Wollongong. (2020, April 1). Global Challenges Program. https://www.uow.edu.au/globalchallenges/our-program/

Zeichner, K. M. (2010). Rethinking the connections between campus courses and field experiences in collegeand university-based teacher education. Journal of Teacher Education, 61(1-2), 89-99. https://doi.org/10.1177/0022487109347671

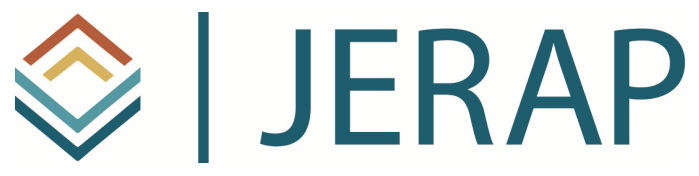

The Journal of Educational Research and Practice is a peerreviewed journal that provides a forum for studies and dialogue about developments and change in the field of education and learning. The journal includes research and related content that examine current relevant educational issues and processes. The aim is to provide readers with knowledge and with strategies to use that knowledge in educational or learning environments. JERAP focuses on education at all levels and in any setting, and includes peer-reviewed research reports, commentaries, book reviews, interviews of prominent individuals, and reports about educational practice. The journal is sponsored by The Richard W. Riley College of Education and Leadership at Walden University, and publication in JERAP is always free to authors and readers. 